\title{
Simultaneous Decrease of Plasma Obestatin and Ghrelin Levels after a High-Carbohydrate Breakfast in Healthy Women
}

\author{
D. SEDLÁČKOVÁ ${ }^{1}$, I. DOSTÁLOVÁ $^{1}$, V. HAINER ${ }^{1}$, L. BERANOVÁ $^{1}$, \\ H. KVASNIČKOVÁ ${ }^{1}$, M. HILL ${ }^{1}$, M. HALUZÍK ${ }^{2}$, J. NEDVÍDKOVÁ ${ }^{1}$ \\ ${ }^{1}$ Institute of Endocrinology, Prague, Czech Republic, ${ }^{2}$ Third Department of Medicine, First Faculty \\ of Medicine, Charles University, Prague, Czech Republic
}

Received November 12, 2007

Accepted January 17, 2008

On-line February 13, 2008

\section{Summary}

Ghrelin is a gut peptide produced mainly by stomach, well known to induce appetite stimulatory actions. Obestatin, a recently identified peptide derived from preproghrelin, was initially described to antagonize stimulatory effect of ghrelin on food intake. The postprandial response of obestatin and its relationship with ghrelin in humans remains unknown. We therefore investigated the postprandial response of obestatin and total ghrelin, acyl and desacyl ghrelin and neuropeptide Y (NPY) to a high-carbohydrate breakfast (1 $604 \mathrm{~kJ}$ ) in eight healthy women (age: $24.2 \pm 0.82$ years; BMI $21.6 \pm 0.61 \mathrm{~kg} / \mathrm{m}^{2}$ ). Blood samples were collected before the meal, and 30,60, 90, 120 and $150 \mathrm{~min}$ after the breakfast consumption. Postprandial plasma obestatin concentrations significantly decreased compared with preprandial levels as well as total ghrelin concentrations and reached the lowest values 90 and $120 \mathrm{~min}$ after the meal consumption, respectively $(p<0.05)$. Plasma acyl and desacyl ghrelin concentrations decreased after the breakfast and reached lowest values in 30 and $60 \mathrm{~min}$, respectively $(p<0.05)$. Plasma NPY concentrations were lower than preprandial levels 90 and 150 min after consuming breakfast $(p<0.05)$. In conclusion, we demonstrated in healthy young women that plasma obestatin concentrations decrease similarly to ghrelin after a highcarbohydrate breakfast.

\section{Key words}

Obestatin • Total ghrelin - Acyl ghrelin - Desacyl ghrelin • Carbohydrate breakfast

\section{Corresponding author}

Jara Nedvídková, Institute of Endocrinology, Národní třída 8, 11694 Prague 1, Czech Republic. Email: jnedvidkova@endo.cz

\section{Introduction}

Ghrelin is a 28-amino acid peptide predominantly produced by the stomach, although its expression has also been confirmed in many other tissues (Kojima et al. 1999, Muccioli et al. 2002, Broglio et al. 2003, Bilgin et al. 2007). Ghrelin has been discovered as a natural ligand of the orphan growth hormone secretagogue (GHS) receptor (GHS-R) type 1a (GHS$\mathrm{R} 1 \mathrm{a})$, which is widely distributed in both central and peripheral tissues (Kojima et al. 2001, Muccioli et al. 2002, Gnanapavan et al. 2002). Ghrelin secretion is mainly under metabolic control as it is increased by fasting and energy restriction but decreased by food intake, glucose and insulin (Lucidi et al. 2002, Shiiya et al. 2002, Ukkola 2003, Broglio et al. 2003, Nedvídková et al. 2003, Flanagan et al. 2003, Dostálová et al. 2007). In agreement with the major influence of nutrition, ghrelin levels are increased in anorexia and cachexia but reduced in obesity (Muccioli et al. 2002, Ukkola 2003, Rosická et al. 2003, Broglio et al. 2003, Dostálová and Haluzík 2007). Ghrelin is the first natural hormone known to date in which the hydroxyl group of one of its serine residues is acylated by n-octanoic acid (Kojima et al. 1999). This acylation is essential for binding to the GHS-R1a receptor, for the GH-releasing capacity of ghrelin and likely also for its other endocrine and physiological actions (Kojima et al. 1999, Matsumoto et al. 2001, Muccioli et al. 2001). However, unacylated ghrelin is not biologically inactive, as acylated ghrelin it exhibits some cardiovascular actions and the ability to modulate cell proliferation (Cassoni et al. 2001, Baldanzi 
et al. 2002, Bedendi et al. 2003) and plays a role in the regulation of food intake (Asakawa et al. 2005). In this context, it is not by chance that unacylated ghrelin circulates at 2.5-fold higher concentration than the acylated form (Kojima et al. 2001, Muccioli et al. 2002).

Ghrelin-associated peptide obestatin is a recently discovered 23-amino acid peptide hormone derived from the same gene as ghrelin, first described by Zhang et al. (2005) to activate the orphan $G$ protein-coupled receptor GPR39. However, several other groups failed to obtain reproducible obestatin binding and signaling in GPR39 receptor transfected cells (Jackson et al. 2006, Holst et al. 2007, Tremblay et al. 2007) even using the same conditions as previously reported by Zhang et al. (2005). Since the discovery of obestatin and its suppressive effect on food intake in fasted/refeded mice (Zhang et al. 2005), the vast majority of subsequent studies (Gourcerol et al. 2006, Samson et al. 2007, Holst et al. 2007, Nogueiras et al. 2007, Yamamoto et al. 2007, Zizzari et al. 2007), except two (Tremblay et al. 2007, Carlini et al. 2007), could not reproduce the initially reported anorexigenic property of obestatin. In addition to the recent controversy over the effects of obestatin, further studies researching peripheral or central injection of obestatin in mice found that it does not affect food intake (Gourcerol et al. 2006, De Smet et al. 2007, Bassil et al. 2007, Nogueiras et al. 2007). The role of human obestatin and the kind of immunoreactivity measured in human has still been highly disputable (Bang et al. 2007, Chartrel et al. 2007) and the interaction between obestatin and ghrelin in the regulation of food intake has also been under question (Seoane et al. 2006, Nogueiras et al. 2007). However, the circulating preprandial ghrelin to obestatinlike immunoreactivity ratio may be of importance in the etiology and pathophysiology of obesity (Guo et al. 2007).

The identification of obestatin as novel peptide hormone derived from the same gene as ghrelin has recently added further complexity to the ghrelin physiology. Despite rapid progress in this field of interest, many questions still remain to be answered, including the regulation of ghrelin and obestatin secretion and their precise physiological endocrine roles. To our best knowledge, no data have been published yet regarding the effect of high-carbohydrate breakfast consumption on postprandial plasma obestatin and total, acyl and desacyl ghrelin response in healthy weight women. Thus, the aim of our study was to characterize plasma obestatin and ghrelin responses to a high- carbohydrate breakfast in healthy women and to investigate the physiological relationship of these hormones with insulin and neuropeptide Y (NPY).

\section{Methods}

\section{Subjects}

This study was performed in accordance with the Declaration of Helsinki and was approved by the Ethic Review Committee of the Institute of Endocrinology in Prague. Prior to the study, all participants provided written informed consent concerning participation in the study.

Eight healthy Czech women (age: $24.2 \pm 0.82$ years; body mass index (BMI) $21.6 \pm 0.61 \mathrm{~kg} / \mathrm{m}^{2}$ ) were enrolled in this study. The women had no history of eating disorders, had normal electrocardiogram (ECG), blood count, liver and renal function. All women had regular menstrual cycles and were in the follicular phase of their cycle at the time of the study. Women were recommended to avoid vigorous physical activity for 24 hours prior to the experiment, consumed a standardized dinner at $6 \mathrm{pm}$ the day before the experiment and were asked not to eat and drink during the night. All participants were admitted to the Institute of Endocrinology at $7.30 \mathrm{am}$. Firstly, all of them underwent physical and ECG examination, and body weight and height measurements. The study took place in a room kept at $23-25^{\circ} \mathrm{C}$ and the women were lying in bed during study. Overall, the study lasted about 3.5 hours and the protocol consisted of high-carbohydrate breakfast consumption and blood withdrawals.

\section{Study design}

Each subject received a high-carbohydrate breakfast with a total energy content of $1604 \mathrm{~kJ}$, consisting of $81.9 \mathrm{~g}$ carbohydrates, $8.8 \mathrm{~g}$ protein and 3.4 $\mathrm{g}$ fat in the form of a white bread roll $(90 \mathrm{~g})$ and strawberry jam $(50 \mathrm{~g})$. In addition, the subjects consumed $250 \mathrm{ml}$ of fruit tea without sugar or other sweetener with the meal. Participants were given 15 minutes to consume their meal.

Blood samples were drawn from the cubital vein using an intravenous cannula, the first blood drawn was collected before meal, and then 30, 60, 90, 120 and 150 min after breakfast consumption. Blood samples were collected into chilled polypropylene tubes containing $\mathrm{Na}_{2}$ EDTA and antilysin. Plasma was immediately separated by $15-$ min centrifugation at $5{ }^{\circ} \mathrm{C}$ and stored at 


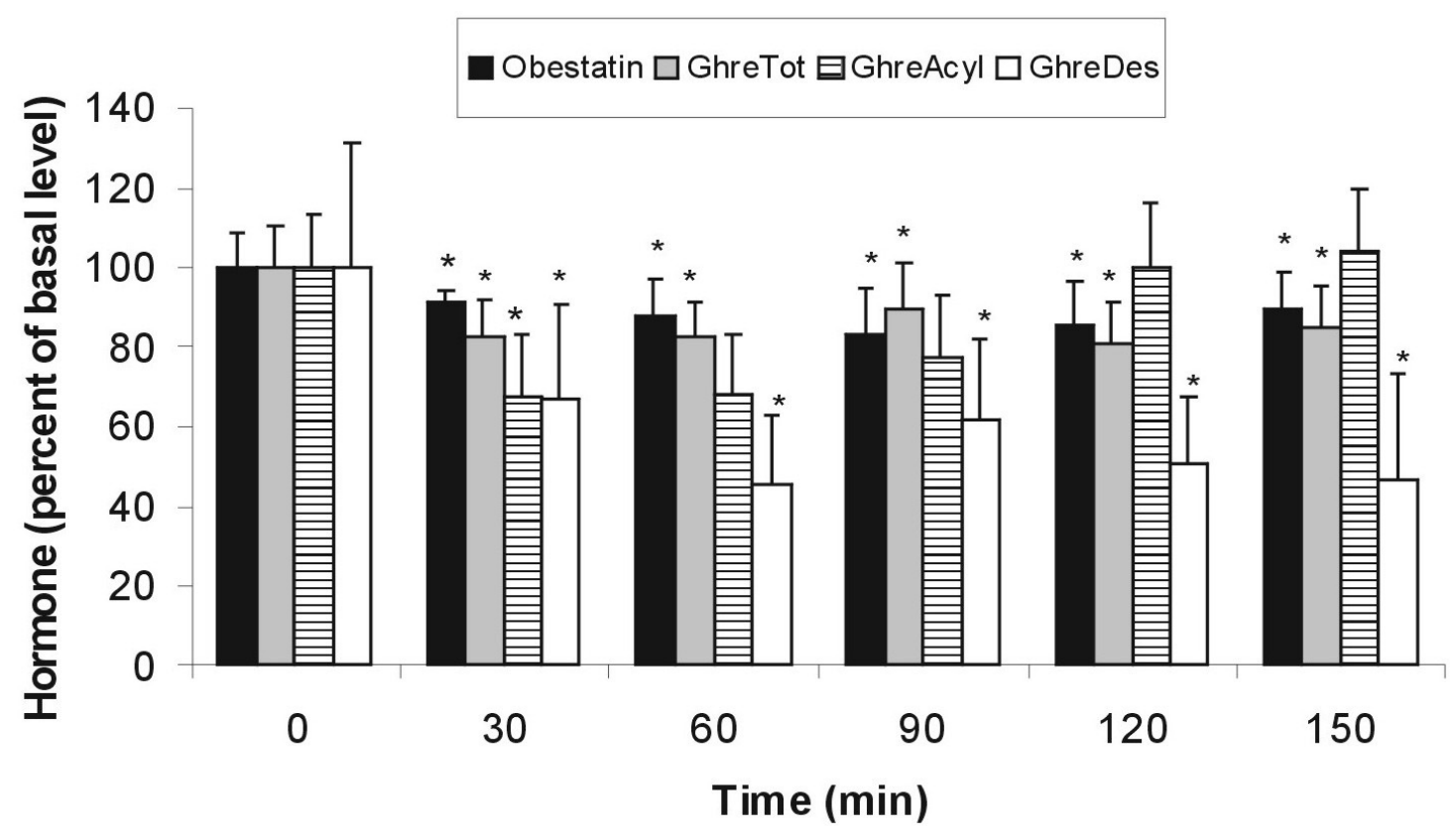

Fig. 1. The percent of postprandial decrease in plasma levels of obestatin, total ghrelin, acyl and desacyl ghrelin. GhreTot - Ghrelin total, GhreAcyl - Ghrelin Acyl, GhreDes - Ghrelin desacyl. *change in hormone level compared with preprandial status (time $\left.0^{\prime}\right), p<0.05$

$-70{ }^{\circ} \mathrm{C}$ until being assayed. Plasma for acyl and desacyl ghrelin assay was acidified by $1 \mathrm{~N} \mathrm{HCl}$ in ratio $1 / 10$ after centrifugation.

\section{Analytical measurements}

Plasma obestatin immunoreactivity was measured with a commercial RIA kit (Phoenix Pharmaceuticals Inc., Belmont, CA, U.S.A.), the intraand interassay variability was $5.0 \%$ and $14.2 \%$, respectively, sensitivity was $50 \mathrm{pg} / \mathrm{ml}$. Total plasma ghrelin, leptin and NPY were determined using commercially available RIA kits (Linco Research, Inc., St. Charles, Missouri, U.S.A.). The intra- and interassay of total ghrelin was $6.4 \%$ and $16.3 \%$, sensitivity 93 $\mathrm{pg} / \mathrm{ml}$; intra- and interassay of leptin was $4.9 \%$ and $4.5 \%$, sensitivity $0.5 \mathrm{ng} / \mathrm{ml}$; intra- and interassay of NPY was $3.3 \%$ and $11.6 \%$, sensitivity $6 \mathrm{pmol} / \mathrm{l}$. Acyl and desacyl plasma ghrelin were determined by ELISA kit (Linco Research, Inc., St. Charles, Missouri, U.S.A.). The intra- and interassay of acyl ghrelin was $4.3 \%$ and $3.5 \%$, sensitivity $2.5 \mathrm{fmol} / \mathrm{ml}$; the intra and interassay of desacyl ghrelin was $3.5 \%$ and $6.7 \%$, sensitivity $12.5 \mathrm{fmol} / \mathrm{ml}$. Plasma insulin levels were determined by commercial RIA kit (Immunotech, Inc., Prague, Czech Republic), the intra- and interassay of insulin was $3.3 \%$ and $2.9 \%$, sensitivity $0.5 \mu \mathrm{IU} / \mathrm{ml}$.

\section{Statistical analysis}

All results are expressed as means \pm SEM. The time courses of dependent variables were evaluated by repeated measures ANOVA model. The differences between subgroups were evaluated using least significant difference multiple comparisons. The statistical significance $p<0.05$ was chosen for both ANOVA testing and multiple comparisons. Due to non-Gaussian data distribution in all dependent variables, the dependent variables underwent power transformations to attain distributional symmetry and a constant variance in the data as well as in residuals. The statistical software NCSS 2002 (Kaysville, UT, USA) was used for data analysis.

\section{Results}

The postprandial responses of the studied hormones are summarized in Table 1. Postprandial plasma obestatin and total ghrelin concentrations significantly decreased compared with preprandial levels and reached their lowest values 90 and $120 \mathrm{~min}$ after meal consumption, respectively $(80.9 \pm 4.89 \%$ and 80.7 $\pm 4.33 \%$, respectively, $p<0.05$ ). Plasma acyl ghrelin concentrations decreased significantly only in 30 . min after the meal $(67.7 \pm 13.67 \%, p<0.05)$. Plasma desacyl ghrelin concentrations decreased significantly after the breakfast and reached the lowest value $60 \mathrm{~min}$ after breakfast $(45.3 \pm 11.88 \%, p<0.05)$ (Fig. 1). Preprandial ghrelin/obestatin ratio was $5.9 \pm 0.5$ and there was no significant change in this ratio during the postprandial period. Plasma insulin concentrations increased 
Table 1. Pre- ( $0 \mathrm{~min})$ and postprandial $(30,60,90,150 \mathrm{~min})$ plasma levels of the studied hormones.

\begin{tabular}{|c|c|c|c|c|c|c|}
\hline & 0 min & $30 \mathrm{~min}$ & $60 \mathrm{~min}$ & $90 \mathrm{~min}$ & $120 \mathrm{~min}$ & $150 \mathrm{~min}$ \\
\hline Obestatin (pg/ml) & $181 \pm 15.3$ & $165 \pm 4.76^{*}$ & $159 \pm 14.8^{*}$ & $150 \pm 17.4^{*}$ & $155 \pm 16.9^{*}$ & $162 \pm 14.7^{*}$ \\
\hline GhreTot $(\mathrm{pg} / \mathrm{ml})$ & $1053 \pm 106$ & $868 \pm 83^{*}$ & $865 \pm 80.9^{*}$ & $942 \pm 110^{*}$ & $850 \pm 90.4^{*}$ & $899 \pm 88.1^{*}$ \\
\hline GhreAcyl (fmol/ml) & $11.61 \pm 1.54$ & $7.86 \pm 1.2 *$ & $7.96 \pm 1.2$ & $8.95 \pm 1.42$ & $11.6 \pm 1.94$ & $12.1 \pm 1.86$ \\
\hline GhreDes (fmol/ml) & $95.9 \pm 29.5$ & $64.3 \pm 15.3^{*}$ & $43.4 \pm 7.63^{*}$ & $59.2 \pm 11.7^{*}$ & $49.0 \pm 8.19^{*}$ & $44.6 \pm 11.9^{*}$ \\
\hline Ghre/Obest & $5.88 \pm 0,50$ & $5.35 \pm 0,33$ & $5.52 \pm 0,32$ & $6.58 \pm 0,95$ & $5.58 \pm 0,51$ & $5.60 \pm 0,35$ \\
\hline Insulin $(\mu I U / m l)$ & $5.71 \pm 0.75$ & $37.8 \pm 5.02 *$ & $35.4 \pm 2.45^{*}$ & $28.9 \pm 2.94 *$ & $30.4 \pm 4.32 *$ & $16.7 \pm 2.82 *$ \\
\hline NPY $(\mathrm{pmol} / \mathrm{l})$ & $47.5 \pm 7.54$ & - & $42.4 \pm 7.26$ & $36.9 \pm 6.93 *$ & - & $36.7 \pm 19.6^{*}$ \\
\hline
\end{tabular}

GhreTot - Ghrelin total, GhreAcyl - Ghrelin acyl, GhreDes - Ghrelin desacyl, Ghre/Obest - Ghrelin/Obestatin ratio, NPY - neuropeptide Y *change in hormone level compared with preprandial status (time $0^{\prime}$ ), $p<0.05$

Table 2. Relationship of obestatin, total ghrelin, acyl and desacyl ghrelin with other measured biochemical and hormonal parameters calculated with all six times $(0,30,60,90,120,150$ min.) included.

\begin{tabular}{|c|c|c|c|c|c|c|c|c|c|}
\hline & & 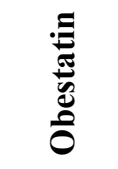 & $\frac{\overrightarrow{0}}{\stackrel{0}{0}}$ & 导 & 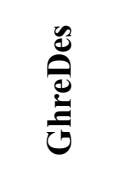 & 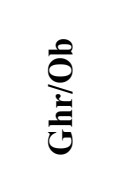 & $\begin{array}{l}\text { 哥 } \\
\stackrel{\overline{\underline{n}}}{\Xi}\end{array}$ & $\bar{z}$ & $\sum_{\infty}^{E}$ \\
\hline \multirow[t]{2}{*}{ Obestatin } & $\mathrm{r}$ & - & 0.661 & 0.284 & 0.460 & -0.309 & -0.143 & 0.805 & -0.197 \\
\hline & $p$ & - & 0.000 & 0.068 & 0.002 & 0.047 & 0.366 & 0.000 & 0.210 \\
\hline \multirow{2}{*}{ GhreTot } & $\mathrm{r}$ & 0.661 & - & 0.363 & 0.666 & 0.414 & -0.190 & 0.490 & -0.048 \\
\hline & $p$ & 0.000 & - & 0.018 & 0.000 & 0.006 & 0.228 & 0.009 & 0.762 \\
\hline \multirow[t]{2}{*}{ GhreAcyl } & $\mathrm{r}$ & 0.284 & 0.363 & - & 0.152 & 0.033 & -0.208 & 0.449 & -0.266 \\
\hline & $p$ & 0.068 & 0.018 & - & 0.336 & 0.836 & 0.187 & 0.019 & 0.089 \\
\hline \multirow[t]{2}{*}{ GhreDes } & $\mathrm{r}$ & 0.460 & 0.666 & 0.152 & - & 0.357 & -0.105 & 0.459 & 0.093 \\
\hline & $p$ & 0.002 & 0.000 & 0.336 & - & 0.020 & 0.506 & 0.016 & 0.557 \\
\hline \multirow[t]{2}{*}{ Ghre/Ob } & $\mathrm{r}$ & -0.309 & 0.414 & 0.033 & 0.357 & - & -0.100 & -0.303 & 0.408 \\
\hline & $p$ & 0.047 & 0.006 & 0.836 & 0.020 & - & 0.530 & 0.124 & 0.007 \\
\hline
\end{tabular}

GhreTot - Ghrelin total, GhreAcyl - Ghrelin Acyl, GhreDes - Ghrelin desacyl, Ghre/Obest - Ghrelin/Obestatin ratio, NPY - neuropeptide $\mathrm{Y}, \mathrm{BMI}-$ Body Mass Index, $r=$ correlation coefficient, $\mathrm{p}=\mathrm{P}$ value ( $\mathrm{p}$ values $<0.05$ are in bold)

significantly after the meal with the highest value in 30 min after the meal $(p<0.05)$. Plasma concentrations of NPY were significantly lower than basal levels in 90 and 150 min after the meal $(p<0.05)$.

The relationship of obestatin with the other studied parameters is shown in Table 2. Obestatin was positively related to total ghrelin, desacyl ghrelin and NPY. Total, acyl and desacyl ghrelin correlated positively to each other and also with NPY. Ghrelin/obestatin ratio was positively related to BMI.

\section{Discussion}

The present study was designed to investigate the effect of a high-carbohydrate breakfast consumption on total, acyl and desacyl ghrelin and ghrelin-associated peptide obestatin in healthy normal-weight women. We demonstrated for the first time that plasma obestatin levels significantly decrease after consumption of a highcarbohydrate breakfast in healthy women in a similar fashion as do total, acyl and desacyl ghrelin. The positive relationship of obestatin with total ghrelin in the postprandial period indicates that these two cleavage products of one gene could act in a similar fashion to increase food intake in healthy humans. This idea is further confirmed by the positive correlation between obestatin and orexigen NPY. However, the relationship of obestatin with the desacyl form of ghrelin does not seem 
to play with the idea of an orexigenic effect of obestatin (Asakawa et al. 2005).

The initially claimed anorexigenic role of obestatin in mice was highly negated by almost all of subsequently published studies (Gourcerol et al. 2006, Samson et al. 2006, Holst et al. 2007, Nogueiras et al. 2007, Yamamoto et al. 2007, Zizzari et al. 2007). No change or a modest reduction $(20 \%)$ in plasma obestatin levels has been reported between non-fasted and fasted state in mice (Zhang et al. 2005, Zizzari et al. 2007). The interaction between obestatin and ghrelin in the regulation of food intake has also been under question. Indeed, while the initial report found that obestatin could reverse the ghrelin-induced stimulation of food intake in fasted mice, such interaction was not confirmed subsequently upon an acute obestatin injection in fed or fasted rats (Seoane et al. 2006) or during the 7-day treatment with obestatin in mice (Nogueiras et al. 2007). Here we show that obestatin exhibits, similarly to ghrelin, postprandial reduction after a high-carbohydrate meal in healthy women, suggesting rather an additive role of these two peptides in postprandial satiation. Furthermore, we negate previous observation of rapid degradation of circulating obestatin as well as no effect of food intake on circulating obestatin levels.

Regarding human studies, the circulating preprandial ghrelin to obestatin ratio was elevated in human obesity, whereas two hours postprandially this ratio was unchanged in obese compared to lean (Guo et al. 2007), rising the hypothesis that the preprandial ghrelin to obestatin ratio may be of importance in the etiology and pathophysiology of obesity. We found the ghrelin/obestatin ratio to be positively related to BMI in healthy young women, whereas neither ghrelin or obestatin correlated to BMI. This might suggest an interesting role of balance between these two hormones as related to other hormonal, metabolic and anthropometric parameters and needs to be further elucidated. However, based on the data of Chartrel et al. (2007), the question about what is really measured in human studies is still unanswered together with the exact role of obestatin as an anorexigenic contraregulator to ghrelin or orexigenic hormone playing in a similar fashion to ghrelin. Bang et al. (2007) found no evidence for the existence of obestatin as an unique, endogenous peptide and the data of this study rather suggest that circulating and stored peptides derived from the carboxyl terminal of proghrelin (C-ghrelin) are consistent in length with proghrelin (29-94) and respond to metabolic manipulation, at least in humans, in similar fashion to ghrelin (1-28). However, our group previously demonstrated that whatever we call immunoreactivity as measured by the Phoenix kit, this molecule is different than ghrelin and exhibits relationships with anthropometric parameters in cases where ghrelin fails to correlate (Hainer et al., unpublished results). It is possible that in certain circumstances, i.e., starvation, the ghrelin gene is cleaved differentially than under physiological conditions. The ratio of ghrelin/obestatin and acyl/desacyl ghrelin may play a role in the regulation of food intake in humans. Another possible explanation of the simultaneous postprandial decrease of obestatin with ghrelin is that the function of obestatin may be to antagonize orexigenic ghrelin action after meal consumption, i.e., some kind of a negative feedback may exist between these two peptides. Our results pointed out the importance of measurement not only of total ghrelin, but also of its acyl and desacyl forms together with other ghrelin gene-derived peptides in order to better interpret the data.

Ghrelin is considered to be an upstream regulator of the orexigenic peptides NPY and AgRP (Rosická et al. 2002, Pfaff et al. 2004, Miura et al. 2006, Dardennes et al. 2007). Recent studies demonstrated a significant enhancement of plasma NPY levels after ghrelin injection in humans (Coiro et al. 2006) and stimulatory action of ghrelin on NPY gene transcription in vitro (Goto et al. 2006). Our results have shown a positive correlation between obestatin, total ghrelin, acyl ghrelin, desacyl ghrelin and NPY. This supports a role of proghrelin-derived peptides in the regulation of food intake and energy storage via NPY, although the mechanisms by which these peptides stimulates NPY neurons are not clear at all.

The postprandial decrease of total ghrelin after a high-carbohydrate breakfast in healthy individuals has been documented several times (Monteleone et al. 2003, Blom et al. 2005, Marzullo et al. 2006). However, what has not yet been established is the role of acyl and desacyl form of ghrelin in the postrandial regulation of satiety. Meal intake significantly suppressed acyl ghrelin by $38 \%$ in healthy humans and serum insulin best predicted plasma acyl ghrelin concentrations accounting for $97 \%$ of its variation (Lucidi et al. 2004). In agreement with this, a high-carbohydrate breakfast significantly decreased serum acyl ghrelin levels in healthy individuals (Tentolouris et al. 2004). In contrast to acylated ghrelin, desacyl ghrelin was shown to induce 
a negative energy balance by decreasing food intake and delaying gastric emptying (Asakawa et al. 2005). Central desacyl ghrelin may activate orexin-expressing neurons in mice, perhaps functioning in feeding regulation (Toshinai et al. 2006). Our results have shown that not only total ghrelin, but also its acyl and desacyl form as well as obestatin significantly decrease after a highcarbohydrate breakfast. What is the role of the individual reduction of these hormones is highly speculative. One hypothesis which has been postulated is that unacylated ghrelin could be used to blunt the effects of acylated ghrelin (Broglio et al. 2004, Gauna et al. 2004) and that the ratio of acylated ghrelin and unacylated ghrelin production might help to regulate the balance between adipogenesis and lipolysis in response to nutritional status (Thompson et al. 2004). The type of relationship that may exist between ghrelin and obestatin has not yet been established, but it is possible that postprandially, obestatin may blunt the effect of ghrelin in healthy humans.

In conclusion, we demonstrated that in healthy women plasma obestatin concentrations decrease similarly to ghrelin after a high-carbohydrate breakfast. Further investigation is needed to classify the role of the cleavage products of the ghrelin gene in human physiology.

\section{Conflict of Interest}

There is no conflict of interest.

\section{Acknowledgements}

The study was supported by grant NR/9158-3 provided by the Czech Ministry of Health. We thank Diana Riegerová, Naděžda Procházková and Jana Novotná for their technical assistance.

\section{References}

ASAKAWA A, INUI A, FUJIMIYA M, SAKAMAKI R, SHINFUKU N, UETA Y, MEGUID MM, KASUGA M: Stomach regulates energy balance via acylated ghrelin and desacyl ghrelin. Gut 54: 18-24, 2005.

BALDANZI G, FILIGHEDDU N, CUTRUPI S, CATAPANO F, BONISSONI S, FUBINI A, MALAN D, BAJ G, GRANATA R, BROGLIO F, PAPOTTI M, SURICO N, BUSSOLINO F, ISGAARD J, DEGHENGHI R, SINIGAGLIA F, PRAT M, MUCCIOLI G, GHIGO E, GRAZIANI A: Ghrelin and des-acyl ghrelin inhibit cell death in cardiomyocytes and endothelial cells through ERK1/2 and PI 3-kinase/AKT. J Cell Biol 159: 10291037, 2002.

BANG AS, SOULE SG, YANDLE TG, RICHARDS AM, PEMBERTON CJ: Characterisation of proghrelin peptides in mammalian tissue and plasma. $J$ Endocrinol 192: 313-323, 2007.

BASSIL AK, HAGLUND Y, BROWN J, RUDHOLM T, HELLSTROM PM, NASLUND E, LEE K, SANGER GJ: Little or no ability of obestatin to interact with ghrelin or modify motility in the rat gastrointestinal tract. $\mathrm{Br} J$ Pharmacol 150: 58-64, 2007.

BEDENDI I, ALLOATTI G, MARCANTONI A, MALAN D, CATAPANO F, GHE C, DEGHENGHI R, GHIGO E, MUCCIOLI G: Cardiac effects of ghrelin and its endogenous derivatives des-octanoyl ghrelin and des-Gln14ghrelin. Eur J Pharmacol 476: 87-95, 2003.

BILGIN HM, TUMER C, DIKEN H, KELLE M. SERMET A: Role of ghrelin in the regulation of gastric acid secretion in rats. Physiol Res 2008 (In press)

BLOM WA, STAFLEU A, DE GRAAF C, KOK FJ, SCHAAFSMA G, HENDRIKS HF: Ghrelin response to carbohydrate-enriched breakfast is related to insulin. Am J Clin Nutr 81: 367-375, 2005.

BROGLIO F, GOTTERO C, ARVAT E, GHIGO E: Endocrine and non-endocrine actions of ghrelin. Horm Res 59: 109-117, 2003.

BROGLIO F, GOTTERO C, PRODAM F, GAUNA C, MUCCIOLI G, PAPOTTI M, ABRIBAT T, VAN DER LELY AJ, GHIGO E: Non-acylated ghrelin counteracts the metabolic but not the neuroendocrine response to acylated ghrelin in humans. J Clin Endocrinol Metab 89: 3062-3065, 2004.

CASSONI P, PAPOTTI M, GHE C, CATAPANO F, SAPINO A, GRAZIANI A, DEGHENGHI R, REISMANN T, GHIGO E, MUCCIOLI G: Identification, characterization, and biological activity of specific receptors for natural (ghrelin) and synthetic growth hormone secretagogues and analogs in human breast carcinomas and cell lines. J Clin Endocrinol Metab 86: 1738-1745, 2001. 
CARLINI VP, SCHIOTH HB, DEBARIOGLIO SR: Obestatin improves memory performance and causes anxiolytic effects in rats. Biochem Biophys Res Commun 352: 907-912, 2007.

CHARTREL N, ALVEAR-PEREZ R, LEPRINCE J, ITURRIOZ X, REAUX-LE GOAZIGO A, AUDINOT V, CHOMARAT P, COGE F, NOSJEAN O, RODRIGUEZ M, GALIZZI JP, BOUTIN JA, VAUDRY H, LLORENS-CORTES C: Comment on "Obestatin, a peptide encoded by the ghrelin gene, opposes ghrelin's effects on food intake". Science 315: 766, 2007.

COIRO V, SACCANI-JOTTI G, RUBINO P, MANFREDI G, MELANI A, CHIODERA P: Effects of ghrelin on circulating neuropeptide Y levels in humans. Neuro Endocrinol Lett 27: 755-757, 2006.

DE SMET B, THIJS T, PEETERS TL, DEPOORTERE I: Effect of peripheral obestatin on gastric emptying and intestinal contractility in rodents. Neurogastroenterol Motil 19: 211-217, 2007.

DARDENNES RM, ZIZZARI P, TOLLE V, FOULON C, KIPMAN A, ROMO L, IANCU-GONTARD D, BONI C, SINET PM, THERESE BLUET M, ESTOUR B, MOUREN MC, GUELFI JD, ROUILLON F, GORWOOD P, EPELBAUM J: Family trios analysis of common polymorphisms in the obestatin/ghrelin, BDNF and AGRP genes in patients with Anorexia nervosa: association with subtype, body-mass index, severity and age of onset. Psychoneuroendocrinology 32: 106-113, 2007.

DOSTÁLOVÁ I, HALUZÍK M.: The role of ghrelin in the regulation of food intake in patients with obesity and anorexia nervosa. Physiol Res 2007 [In press].

DOSTÁLOVÁ I, SMITKA K, PAPEŽOVÁ H, KVASNIČKOVÁ H, NEDVÍDKOVÁ J: Increased insulin sensitivity in patients with anorexia nervosa: the role of adipocytokines. Physiol Res 56: 587-594, 2007.

FLANAGAN DE, EVANS ML, MONSOD TP, RIFE F, HEPTULLA RA, TAMBORLANE WV, SHERWIN RS: The influence of insulin on circulating ghrelin. Am J Physiol Endocrinol Metab 284: E313-E316, 2003.

GAUNA C, MEYLER FM, JANSSEN JA, DELHANTY PJ, ABRIBAT T, VAN KOETSVELD P, HOFLAND LJ, BROGLIO F, GHIGO E, VAN DER LELY AJ: Administration of acylated ghrelin reduces insulin sensitivity, whereas the combination of acylated plus unacylated ghrelin strongly improves insulin sensitivity. $J$ Clin Endocrinol Metab 89: 5035-5042, 2004.

GNANAPAVAN S, KOLA B, BUSTIN SA, MORRIS DG, MCGEE P, FAIRCLOUGH P, BHATTACHARYA S, CARPENTER R, GROSSMAN AB, KORBONITS M: The tissue distribution of the mRNA of ghrelin and subtypes of its receptor, GHS-R, in humans. J Clin Endocrinol Metab 87: 2988-2991, 2002.

GOURCEROL G, MILLION M, ADELSON DW, WANG Y, WANG L, RIVIER J, ST-PIERRE DH, TACHE Y: Lack of interaction between peripheral injection of CCK and obestatin in the regulation of gastric satiety signaling in rodents. Peptides 27: 2811-2819, 2006.

GOTO M, ARIMA H, WATANABE M, HAYASHI M, BANNO R, SATO I, NAGASAKI H, OISO Y: Ghrelin increases neuropeptide $\mathrm{Y}$ and agouti-related peptide gene expression in the arcuate nucleus in rat hypothalamic organotypic cultures. Endocrinology 147: 5102-5109, 2006.

GUO ZF, ZHENG X, QIN YW, HU JQ, CHEN SP, ZHANG Z: Circulating preprandial ghrelin to obestatin ratio is increased in human obesity. J Clin Endocrinol Metab 92: 1875-1880, 2007.

HOLST B, EGEROD KL, SCHILD E, VICKERS SP, CHEETHAM S, GERLACH LO, STORJOHANN L, STIDSEN CE, JONES R, BECK-SICKINGER AG, SCHWARTZ TW: GPR39 signaling is stimulated by zinc ions but not by obestatin. Endocrinology 148: 13-20, 2007.

JACKSON VR, NOTHACKER HP, CIVELLI O: GPR39 receptor expression in the mouse brain. Neuroreport 17: 813 816, 2006.

KOJIMA M, HOSODA H, DATE Y, NAKAZATO M, MATSUO H, KANGAWA K: Ghrelin is a growth-hormonereleasing acylated peptide from stomach. Nature 402: 656-660, 1999.

KOJIMA M, HOSODA H, MATSUO H, KANGAWA K: Ghrelin: discovery of the natural endogenous ligand for the growth hormone secretagogue receptor. Trends Endocrinol Metab 12: 118-122, 2001.

LUCIDI P, MURDOLO G, DI LORETO C, DE CICCO A, PARLANTI N, FANELLI C, SANTEUSANIO F, BOLLI GB, DE FEO P: Ghrelin is not necessary for adequate hormonal counterregulation of insulin-induced hypoglycemia. Diabetes 51: 2911-2014, 2002. 
LUCIDI P, MURDOLO G, DI LORETO C, PARLANTI N, DE CICCO A, RANCHELLI A, FATONE C, TAGLIONI C, FANELLI C, SANTEUSANIO F, DE FEO P: Meal intake similarly reduces circulating concentrations of octanoyl and total ghrelin in humans. $J$ Endocrinol Invest 27: RC12-RC15, 2004.

MARZULLO P, CAUMO A, SAVIA G, VERTI B, WALKER GE, MAESTRINI S, TAGLIAFERRI A, Di BLASIO AM, LIUZZI A: Predictors of postabsorptive ghrelin secretion after intake of different macronutrients. $J$ Clin Endocrinol Metab 91: 4124-4130, 2006.

MATSUMOTO M, KITAJIMA Y, IWANAMI T, HAYASHI Y, TANAKA S, MINAMITAKE Y, HOSODA H, KOJIMA M, MATSUO H, KANGAWA K: Structural similarity of ghrelin derivatives to peptidyl growth hormone secretagogues. Biochem Biophys Res Commun 284: 655-659, 2001.

MIURA T, MARUYAMA K, SHIMAKURA S, KAIYA H, UCHIYAMA M, KANGAWA K, SHIODA S, MATSUDA K: Neuropeptide Y mediates ghrelin-induced feeding in the goldfish, Carassius auratus. Neurosci Lett 407: 279-283, 2006.

MONTELEONE P, BENCIVENGA R, LONGOBARDI N, SERRITELLA C, MAJ M: Differential responses of circulating ghrelin to high-fat or high-carbohydrate meal in healthy women. $J$ Clin Endocrinol Metab 11: 5510-5514, 2003.

MUCCIOLI G, PAPOTTI M, LOCATELLI V, GHIGO E, DEGHENGHI R: Binding of 125I-labeled ghrelin to membranes from human hypothalamus and pituitary gland. J Endocrinol Invest 24: RC7-RC9, 2001.

MUCCIOLI G, TSCHOP M, PAPOTTI M, DEGHENGHI R, HEIMAN M, GHIGO E: Neuroendocrine and peripheral activities of ghrelin: implications in metabolism and obesity. Eur J Pharmacol 440: 235-254, 2002.

NEDVÍDKOVÁ J, KRYKORKOVÁ I, BARTÁK V, PAPEŽOVÁ H, GOLD PW, ALESCI S, PACÁK K: Loss of meal-induced decrease in plasma ghrelin levels in patients with anorexia nervosa. $J$ Clin Endocrinol Metab 88: 1678-1682, 2003.

NOGUEIRAS R, PFLUGER P, TOVAR S, ARNOLD M, MITCHELL S, MORRIS A, PEREZ-TILVE D, VAZQUEZ MJ, WIEDMER P, CASTANEDA TR, DIMARCH R, TSCHOP M, SCHURMANN A, JOOST HG, WILLIAMS LM, LANGHANS W, DIEGUEZ C: Effects of obestatin on energy balance and growth hormone secretion in rodents. Endocrinology 148: 21-26, 2007.

PFAFF DW, PHILLIPS MI, RUBIN RT: Principles of Hormone/Behaviour Relations. Elsevier Academic Press, London, 2004, pp 335.

ROSICKÁ M, KRŠEK M, JARKOVSKÁ Z, MAREK J, SCHREIBER V: Ghrelin - a new endogenous growth hormone secretagogue. Physiol Res 51: 435-441, 2002.

ROSICKÁ M, KRŠEK M, MATOULEK M, JARKOVSKÁ Z, MAREK J, JUSTOVÁ V, LACINOVÁ Z: Serum ghrelin levels in obese patients: the relationship to serum leptin levels and soluble leptin receptors levels. Physiol Res 52: 61-66, 2003.

SAMSON WK, WHITE MM, PRICE C, FERGUSON AV: Obestatin acts in brain to inhibit thirst. Am J Physiol 292: R637-R643, 2007.

SEOANE LM, AL-MASSADI O, PAZOS Y, PAGOTTO U, CASANUEVA FF: Central obestatin administration does not modify either spontaneous or ghrelin-induced food intake in rats. J Endocrinol Invest 8: RC13-RC15, 2006.

SHIIYA T, NAKAZATO M, MIZUTA M, DATE Y, MONDAL MS, TANAKA M, NOZOE S, HOSODA H, KANGAWA K, MATSUKURA S: Plasma ghrelin levels in lean and obese humans and the effect of glucose on ghrelin secretion. J Clin Endocrinol Metab 87: 240-244, 2002.

TENTOLOURIS N, KOKKINOS A, TSIGOS C, KYRIAKI D, DOUPIS J, RAPTIS SA, KATSILAMBROS N: Differential effects of high-fat and high-carbohydrate content isoenergetic meals on plasma active ghrelin concentrations in lean and obese women. Horm Metab Res 36: 559-563, 2004.

THOMPSON NM, GILL DA, DAVIES R, LOVERIDGE N, HOUSTON PA, ROBINSON IC, WELLS T: Ghrelin and des-octanoyl ghrelin promote adipogenesis directly in vivo by a mechanism independent of the type 1a growth hormone secretagogue receptor. Endocrinology 145: 234-242, 2004. 
TOSHINAI K, YAMAGUCHI H, SUN Y, SMITH RG, YAMANAKA A, SAKURAI T, DATE Y, MONDAL MS, SHIMBARA T, KAWAGOE T, MURAKAMI N, MIYAZATO M, KANGAWA K, NAKAZATO M: Desacyl ghrelin induces food intake by a mechanism independent of the growth hormone secretagogue receptor. Endocrinology 147: 2306-2314, 2006.

TREMBLAY F, PERREAULT M, KLAMAN LD, TOBIN JF, SMITH E, GIMENO RE: Normal food intake and body weight in mice lacking the G protein-coupled receptor GPR39. Endocrinology 148: 501-506, 2007.

UKKOLA O: Endocrinological activities of ghrelin: new insights. Eur J Int Med 14: 351-356, 2003.

YAMAMOTO D, IKESHITA N, DAITO R, HERNINGTYAS EH, TODA K, TAKAHASHI K, IIDA K, TAKAHASHI Y, KAJI H, CHIHARA K, OKIMURA Y: Neither intravenous nor intracerebroventricular administration of obestatin affects the secretion of GH, PRL, TSH and ACTH in rats. Regul Pept 138: 141-144, 2007.

ZHANG JV, REN PG, AVSIAN-KRETCHMER O, LUO CW, RAUCH R, KLEIN C, HSUEH AJ: Obestatin, a peptide encoded by the ghrelin gene, opposes ghrelin's effects on food intake. Science 310: 996-999, 2005.

ZIZZARI P, LONGCHAMPS R, EPELBAUM J, BLUET-PAJOT MT: Obestatin partially affects ghrelin stimulation of food intake and growth hormone secretion in rodents. Endocrinology 148: 1648-1653, 2007. 